\title{
Surfactant Modified Zeolite from Cyclone Ash as Adsorbent for Removal of Reactive Orange 16 from Aqueous Solution
}

\author{
Denise A. Fung aro", Sueli I. Borrely, Terezinha E.M. Carvalho \\ Nuclear and Energy Research Institute (IPEN - CNEN/SP), São Paulo, Brazil \\ *Corresponding author: dfungaro@ipen.br
}

Received December 20, 2012; Revised February 19, 2013; Accepted March 02, 2013

\begin{abstract}
Zeolite synthesized from cyclone ash (ZCA) was modified with various loadings of hexadecyltrimethylammonium bromide (HDTMA-Br) and was used as adsorbent to remove Reactive Orange 16 (RO16), an azo reactive dye, from aqueous solution. The RO16 adsorption efficiencies for ZCA and surfactantmodified zeolites from cyclone ash (SMZCAs) were compared. SMZCAs presented higher RO16 adsorption efficiency than ZCA, and SMZCA with higher loading amount of HDTMA-Br exhibited higher RO16 adsorption efficiency. A series of experiments was conducted to examine the effects of contact time, solution $\mathrm{pH}$, and adsorbent dosage on dye removal. The adsorption kinetic of RO16 onto adsorbents was discussed using the pseudo-first order, pseudo-second order and intra-particle diffusion models, and the pseudo-second order model provided the best correlation of the experimental data. The equilibrium adsorption data were well represented by Langmuir isotherm model with maximum adsorption capacity of 0.58 and $12.6 \mathrm{mg} \mathrm{g}^{-1}$ for ZCA and SMZCA, respectively.The toxicity tests of dye solutions before and after the adsorption treatment were evaluated with D. simlis and V.ficheri.
\end{abstract}

Keywords: reactive azo dye; cyclone ash, zeolite, cationic surfactant

\section{Introduction}

In Brazil, the coal used in power plants is pulverized and burned inside a boiler, producing bottom ash (15-20 wt.\%) of the bulk solid combustion-by-products produced), which falls inside the boiler, and fly ash (80-85 wt.\%) [1]. The fly ash is a fine-grained, powdery particulate material that is carried off in the flue gas and usually collected from the flue gas by means of electrostatic precipitators, baghouses, or mechanical collection devices such as cyclones [2].

Cyclones are low-cost, low-maintenance centrifugal collectors that are typically used to remove particulates in the size range of 10-100 microns. The cyclone fly ash is the ash fraction that has been carried through the flue gas channels into the cyclone and precipitated there. Technically speaking, cyclone ash is the ash fraction that has been trapped in the cyclone.

During combustion most of the heavy metals in the fuel are retained in the ash. The various ash fractions such as bottom ash, cyclone ash and baghouse filter ash may contain relatively high concentrations of heavy metals [3]. Combustion acts like a thermodynamic separation process for the different inorganic materials in the fuel. Elements with a low volatility will concentrate in the bottom ash, while more volatile elements will concentrate in the fly ash [4]. The consequence of this separation effect in combustion plants is that the different ash fractions have a different chemical composition. Before ash residue can be utilized or disposed of in a landfill, its chemical as well as extraction (leaching) characteristics must be known.

Fly ash from baghouse filter produced in the Brazilian power plant is mostly recycled as cement raw material to be used in civil engineering materials. However, cyclone ash does not find at present time a commercial application; rather, it is usually stored in abandoned surface mine or dumped in landfills in the vic inity of the power plant.

The main drawback of coal-fired power plants in Brazil is the high production of ash. The synthes is of zeolites has produced an environmentally friendly and economically viable way of recycling coal fly ash. The initial findings indicate that zeolite synthesized from Brazilian fly ash used as low cost adsorbent has high adsorptive capacity for dyes from water $[5,6,7]$.

It is known that although zeolites have little affinity toward organic pollutants, permanent negative charges in their crystal structures enable them to be modified by cationic surfactants so that they better retain organic pollutants $[8,9,10]$.

The most commonly used surfactant for zeolite surface modification is hexadecyltrimethylammonium bromide (HDTMA-Br), in which each molecule is composed of a hydrophilic and positively charged head group, and a hydrophobic tail. HDTMA-Br may form monolayers and/or bi-layers on the zeolite surface [11,12,13,14,15].

It is proposed that cyclone ash be used as raw material for zeolite synthesis. To the best of the authors' knowledge, the preparation of surfactant-modified zeolite synthesis from cyclone ash and the removal of dyes by this adsorbent have never been reported. Cyclone ash 
samples contained larger particles than fabric filter and electrostatic precipitator ash samples and showed lower cytotoxicity, very little mutagenicity and lower concentrations of trace ele ments $[1,16]$.

Reactive Orange 16 (RO16) is one of the reactive azo dyes most intensively produced and used globally. High water solubility, excellent coloring properties and covalent bonding with both natural and synthetic textile fibers are the major advantages of this dye class. The reactive dyeing process is accompanied by the loss of $10-50 \%$ of the dye due to a hydrolysis reaction involving the vinyl group (dye) under alkaline dyeing conditions, giving rise to a highly colored effluent [17].

Comparative use of bacterial, algal and protozoan tests to study toxicity of various dyes was evaluated. RO16 was the only dye tested that exhibited mutagenic effects in both the presence and absence of metabolic activation, which indicated that both substitution and frameshift mutations were induced by the compound acting like a direct and indirect mutagen [18].

In a previous paper [19] it was proposed, the use of zeolite from fly ash collected in baghouse filter as an adsorbent for the removal of reactive orange 16 from aqueous solution. Continuing the application of this adsorbent, in the present work, we investigated the adsorption capacities of surfactant-modified zeolite from cyclone fly ash. This study helps to understand the adsorption properties and potential applications of unmodified and modified zeolites for dye removal from aqueous environments.

\section{Experimental}

\subsection{Materials}

All the reagents used for experimental studies were of analytical grade. The samples of coal fly ash from cyclone filter (CCA) were obtained from a coal-fired power plant located at Figueira County, in Paraná State, Brazil. The quaternary ammonium salt hexadecyltrimethylammonium bromide (HDTMA-Br, Merck), with molar mass $364.46 \mathrm{~g}$ $\mathrm{mol}^{-1}$ and minimum $99 \%$ active substance, was used. Reactive Orange 16 dye (RO16; C.I. 17757; $\left.\mathrm{C}_{20} \mathrm{H}_{17} \mathrm{~N}_{3} \mathrm{Na}_{2} \mathrm{O}_{11} \mathrm{~S}_{3} ; 617.54 \mathrm{~g} \mathrm{~mol}^{-1} ; \lambda_{\max }=493 \mathrm{~nm}\right)$ was obtained from Sig ma-A ldrich with a dye content of $50 \%$ and was used without further purification. A stock solution of RO16 was prepared in double distilled water and the solutions for adsorption tests were prepared by diluting it. Concentrations of the aqueous solutions of dye were monitored on UV/Vis ible spectrophotometer (Varian model Cary 1E). As shown in Figure 1, RO16 has two sulfonate groups, which have negative charges in aqueous solution.

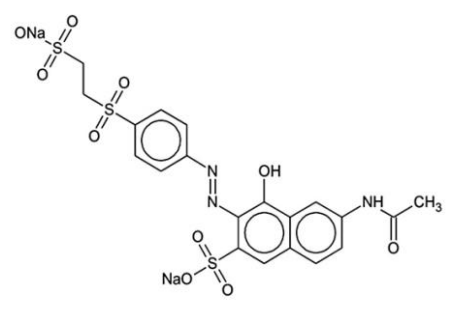

Figure 1. Chemical structure of Reactive Orange 16

\subsection{Synthesis of Surfactant-modified Zeolite from Cyclone Fly Ash}

CCA (30g) was mixed with $240 \mathrm{~mL}$ of $3.5 \mathrm{~mol} \mathrm{~L}^{-1}$ aqueous $\mathrm{NaOH}$ solution in a $300 \mathrm{~mL}$ Teflon vessel. This mixture was heated to $100^{\circ} \mathrm{C}$ in oven for $24 \mathrm{~h}$. After fin ishing of the process, the suspension was filtered with 4A quantitative filter paper. The zeolite from cyclone fly ash (ZCA) was repeatedly washed with deionized water until the $\mathrm{pH}$ of washing water reach $\sim 11$ and dried at $50^{\circ} \mathrm{C}$ for $12 \mathrm{~h}$ [20]. Twenty-five grams of ZCA were mixed with $0.5 \mathrm{~L}$ of HDTMA-Br solution at varied concentrations ranged between $0.9 \mathrm{mmol} \mathrm{L}^{-1}$ and $20 \mathrm{mmol}$ $\mathrm{L}^{-1}$. The mixture of zeolite and HDTMA-Br solution was stirred for $7 \mathrm{~h}$ at $120 \mathrm{rpm}$ and $25^{\circ} \mathrm{C}$. The suspension was filtered and the solid was dried in oven at $50^{\circ} \mathrm{C}$ for $12 \mathrm{~h}$ [11]. Zeolites modified with 0.9, 1.8, 9.0, and $20 \mathrm{mmol} \mathrm{L}^{-1}$ of HDTMA-Br solutions were named as SMZCA-0.9, SMZCA-1.8 and SMZCA-20, respectively. SMZCA-20 was selected for characterizations.

\subsection{Characterization of Materials}

Instrumental neutron activation analysis (INAA) was used to determine concentrations of e lements of materials. About 100mg of CCA, ZCA, SMZCA-20 and reference material were weighted in polyethylene bags. The accuracy of the results was determined using IAEA standard reference material SOIL-7. For irradiation, the samples, reference material and element standards were simultaneously submitted to a thermal neutron flux in the range of 3.5 to $5.0 \times 10^{12} \mathrm{n} \mathrm{cm}^{-2} \mathrm{~s}^{-1}$ for $8 \mathrm{~h}$ at the nuclear research reactor IEA-R1 of the Nuclear and Energy Research Institute, (IPEN/CNEN-SP), São Paulo, Brazil. After appropriate decay periods, $\gamma$-ray spectra of samples, reference material and element standards were measured using High-purity Ge (HPGe) detector Model POP-TOP (EG\&G Ortec, Oak Ridge, TN, USA). This detector was coupled to an EG\&G Ortec card and as sociated electronics. Spectrum analysis was carried out using VISPECT software, in TURBOBASIC language. The particle size of the materials was measured using a laser based particle size analyzer, namely a Malvern MSS Mastersizer 2000 Ver. 5.54.

\subsection{Adsorption Studies}

The adsorption was performed using the batch procedure. Kinetic experiments were carried out by shaking $0.1 \mathrm{~g}$ of adsorbents ZCA and SMZCA-20 with $10 \mathrm{~mL}$ of RO16 solutions with an initial concentration of $25 \mathrm{mg} \mathrm{L} \mathrm{L}^{-1}$ at room temperature $\left(25 \pm 2{ }^{\circ} \mathrm{C}\right)$ in a shaker operated at $120 \mathrm{rpm}$ for $1-150 \mathrm{~min}$ in glass bottles. The samples were withdrawn from the shaker at different time intervals, centrifuged and the concentration in the supernatant solution was determined. For adsorption isotherms, RO16 solutions of different concentrations ranging from 25 to $125 \mathrm{mg} \mathrm{L}^{-1}$ for SMZCA-20 and 2.0 to $14.0 \mathrm{mg} \mathrm{L}^{-1}$ for $\mathrm{ZCA}$ were agitated till the equilibriu $\mathrm{m}$ was achieved at room temperature $\left(25 \pm 2{ }^{\circ} \mathrm{C}\right)$. Each experiment was duplicated under identical conditions with maximu m deviation was found to be $3 \%$.

The effect of the adsorbent dosage was tested by mixing $0.02-0.2 \mathrm{~g}$ SMZCA-20 with $10 \mathrm{~mL}$ of RO16 solution at $50 \mathrm{mg} \mathrm{L}^{-1}$ for $60 \mathrm{~min}$. The effect of $\mathrm{pH}$ on 
adsorption of dye onto SMZCA-20 was determined over the $\mathrm{pH}$ range of 2 to 10.5 at an initial $\mathrm{RO} 16$ concentration of $50 \mathrm{mg} \mathrm{L}^{-1}$ and the $\mathrm{pH}$ was adjusted by adding 0.1 or $0.01 \mathrm{~mol} \mathrm{~L}^{-1}$ of $\mathrm{HNO}_{3}$ or $\mathrm{NaOH}$.

The amount of the dye uptake and percentage of dye removal by the adsorbent were calculated by applying Eqs. (1) and (2), respectively:

$$
\begin{aligned}
q_{t} & =\frac{(C o-C t) V}{M} \\
R(\%) & =\frac{(C o-C t)}{C o} \times 100
\end{aligned}
$$

where $\mathrm{q}_{\mathrm{t}}$ is the adsorbed amount of adsorbate per gram of adsorbent at any time $\mathrm{t}\left(\mathrm{mg} \mathrm{g}^{-1}\right), \mathrm{C}_{0}$ and $\mathrm{C}_{\mathrm{t}}$ the concentrations of the adsorbate in the initial solution and at any time $\mathrm{t}$, respectively $\left(\mathrm{mg} \mathrm{L}^{-1}\right) ; \mathrm{V}$ the volume of the adsorbate solution added (L) and $\mathrm{M}$ the amount of the adsorbent used (g).

\subsubsection{Kinetic and Equilibrium Models}

In order to investigate the mechanis $m$ of adsorption, characteristic constants were determined using the linearized form of pseudo-first order (Eq. 3) and pseudosecond order (Eq. 4) kinetic models with equations as follows:

$$
\begin{gathered}
\log (q e-q t)=\log q e-\frac{k_{1} t}{2.303} \\
\frac{t}{q t}=\frac{1}{k_{2} q e^{2}}-\frac{1}{q e} t
\end{gathered}
$$

where $q_{e}$ is the amount of dye adsorbed at equilibriu m (mg $\left.\mathrm{g}^{-1}\right), q t$ is the amount of dye adsorbed at time $t\left(\mathrm{mg} \mathrm{g}^{-1}\right)$, $k_{l}$ is the rate constant of the pseudo-first-order adsorption $\left(\min ^{-1}\right)$, and $k_{2}$ is the rate constant of the pseudo-secondorder kinetics $\left(\mathrm{g} \mathrm{mg}^{-1} \mathrm{~min}^{-1}\right)[21,22,23]$. The values of $k_{l}$ and $q_{e}$ were obtained from the slope and intercept respectively of plot of $\log \left(q_{e}-q t\right)$ versus $t$ for pseudofirst order model. The values of $q_{e}$ and $k_{2}$ can be determined from the slope and intercept of a plot of $t / q t$ versus $t$, respectively for pseudo-second-order model.

The in itial adsorption rate, $\mathrm{h}\left(\mathrm{mg} \mathrm{g}^{-1} \mathrm{~min}^{-1}\right)$, as $\mathrm{t} \rightarrow 0$ can be defined as (equation 5):

$$
h=k_{2} q_{e^{2}}
$$

where $k_{2}$ is the rate constant of the pseudo-second order kinetics $\left(\mathrm{g} \mathrm{mg}^{-1} \mathrm{~min}^{-1}\right)$ and $q_{e}$ is the maximu $\mathrm{m}$ adsorption capacity $\left(\mathrm{mg} \mathrm{g}^{-1}\right)$.

The kinetic results were analyzed by the intraparticle diffusion model to elucidate the diffusion mechanis $\mathrm{m}$, which model is expressed as [24]:

$$
q t=k_{i d} t^{0.5}+C
$$

where $k_{\mathrm{id}}$ is the intraparticle diffusion rate constant $\left(\mathrm{mg} \mathrm{g}^{-1}\right.$ $\left.\min ^{-0.5}\right)$. According to Eq. (6), a plot of $q t$ versus $t^{05}$ should be a straight line with a slope $k_{\text {id }}$ and intercept $C$ when adsorption mechanism follows the intraparticular diffusion process.

The equilibriu m data obtained in the present study were analyzed using the linear forms of the expressions of
Langmuir (Eq (7)) and Freundlich (Eq (8)) isotherm models:

$$
\begin{gathered}
\frac{C_{e}}{q_{e}}=\frac{1}{Q_{o} b}+\frac{C_{e}}{Q_{o}} \\
\log \mathrm{q}_{\mathrm{e}}=\log \mathrm{K}_{\mathrm{f}}+\frac{1}{n} \log C_{e}
\end{gathered}
$$

where $\mathrm{C}_{\mathrm{e}}$ is the equilibrium concentration $\left(\mathrm{mg} \mathrm{L}^{-1}\right), \mathrm{q}_{\mathrm{e}}$ the amount adsorbed at equilibrium $\left(\mathrm{mg} \mathrm{g}^{-1}\right), \mathrm{Q}_{0}$ is the maximum amount of adsorbate per unit weight of adsorbent to form a complete monolayer on the surface $\left(\mathrm{mg} \mathrm{g}^{-1}\right) ; \mathrm{b}$ is the Langmuir isotherm constant $\left(\mathrm{Lmg}^{-1}\right)$, related to the affinity of the adsorption sites; $\mathrm{K}_{\mathrm{F}}\left[\left(\mathrm{mg} \mathrm{g}^{-1}\right)\right.$ $\left.\left(\mathrm{L} \mathrm{mg}^{-1}\right)^{1 / \mathrm{n}}\right]$ and $\mathrm{n}$ are the Freundlich constants related to adsorption capacity and adsorption intensity of adsorbents, respectively.

The non-linear regression Chi-square $\left(\chi^{2}\right)$ test, represented by Eq. (9), was employed as a criterion for the fitting quality due to the inherent bias resulting from linearization of isotherm models [25].

$$
\chi^{2}=\sum \frac{\left(q_{e} \exp -q_{e} c a l c\right)^{2}}{q_{e} \text { calc }}
$$

where $q_{\mathrm{e}} \exp$ is the equilibrium capacity of the adsorbent obtained from experiment $\left(\mathrm{mg} \mathrm{g}^{-1}\right)$, and $q_{\mathrm{e}}$ calc is the equilibrium capacity obtained by calculating from the model $\left(\mathrm{mg} \mathrm{g}^{-1}\right)$. A low value of $\chi^{2}$ indicates that experimental data fit better to the value from the model.

\subsection{Toxicity Assessments}

Young individuals of Daphnia similis were exposed to different concentration of dye (from $6.25 \mathrm{mg} \mathrm{L}^{-1}$ to $100.0 \mathrm{mg} \mathrm{L}^{-1}$ ), during $48 \mathrm{~h}$. The concentrations that could lead to the immobilization of $50 \%$ of the organis $\mathrm{ms}\left(\mathrm{EC}_{50}\right)$ were calculated from the number of immobile organisms per sample concentration and by applying statistical tests with the program Trimmed Spearman Karber [26]. The experiment with the bioluminescent bacteria Vibrio fischeri was performed with the Microtox System, model M-500 from Microbics, exposing the samples to concentrations between $10.23 \mathrm{mg} \mathrm{L}^{-1}$ and $81.90 \mathrm{mg} \mathrm{L}^{-1}$ during $15 \mathrm{~min}$. The statistical analys is was carried out with proper statistics program by Microbics (version 7.82), that calculates the values of $\mathrm{EC}_{50}$ based on the reduction of the $50 \%$ of light emitted by the microorganis $\mathrm{m}$ after exposure [27].

\section{Results and Discussion}

\subsection{Effect of Initial Surfactant on Dye Adsorption}

In order to investigate the effect of HDTMA concentration on removal of RO16 HDTMA concentration was used as $0.9,1.8,9.0$ and $20 \mathrm{mmol} \mathrm{L}^{-1}$ while initial RO16 concentration was $10 \mathrm{mg} \mathrm{L}^{-1}$. As it can be seen from Table 1 and Figure 2, with augmentation of HDTMA, removal efficiency of RO16 enhanced and maximum dye removal was observed at $20 \mathrm{mmol} \mathrm{L}^{-1}$ surfactant concentration. 
Table1. Effect of su rfactant loading on fly ash based zeolites on percentage removal of $\mathrm{RO} 16$

\begin{tabular}{|c|c|c|}
\hline Adsorbent Type & [HDTMA-Br] $\left(\mathrm{mmol} \mathrm{L}^{-1}\right)$ & Removal $(\%)$ \\
\hline ZCA & 0 & 25.6 \\
\hline SMZCA-0.9 & 0.9 & 27.9 \\
\hline SMZCA-1.8 & 1.8 & 36.4 \\
\hline SMZCA-9 & 9.0 & 94.4 \\
\hline SMZCA-20 & 20 & 99.8 \\
\hline
\end{tabular}

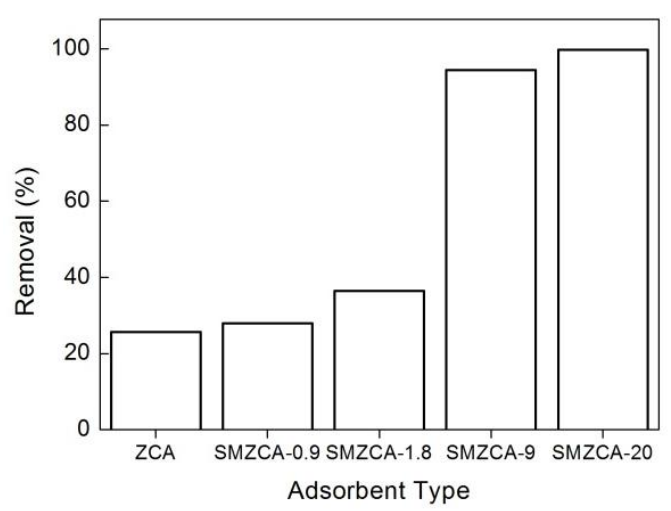

Figure 2. RO16 percentage removal by different adsorbents Chemical structure of Reactive Orange 16

Thus treatment of zeolite with initial concentration of $20 \mathrm{mmol} \mathrm{L}^{-1}$ of surfactant appears to be the optimal loading for RO16 removal and was selected to be used in remaining experiments. The theoretical critical micelle concentration (CMC) of HDTMA-Br is about $0.9 \mathrm{mmol} \mathrm{L}^{-1}$ [10] and this initial concentration exceeds the critical micelle concentration of the surfactant. It is therefore envisaged that these micelles attach as such to the external surface and then rearrange to form a patchy mono-layer and/or bi-layers that tends to impart anionic exchange and hydrophobic characteristics to the adsorbent [11].

\subsection{Characterization of the Materials}

The characterizations of ZCA and SMZCA-20 have been described in detail in previous paper [11]. Some important physicochemical characteristics of ZCA and SMZCA-20 materials with respect to this study are shown in Table 2.

The XRD analyses of two zeolitic materials showed that hydroxysodalite (ICDD 00-011-0401) was the major zeolitic phase with peaks of quartz (ICDD001-0649) and mullite (ICDD002-0430) of fly ash that remained after the alkaline hydrothermal treat ment. The structural parameters of SMZCA-20 are very close to that of corresponding parent zeolite which indicate that the crystalline nature of the zeolite material remained intact after required chemical treatment with HDTMA molecules and heating treatment for drying [11].

Laser granulo metric analys is results for CCA, ZCA and SMZCA-20 samples are reported both as absolute and cumulative volumetric distributions (Figure 3). The particle size distributions of materials are given in Table 3. These distributions specify that the majority of particles (90\%) lie below 174.8, 291.8 and $230.0 \mu \mathrm{m}$ in case of CCA, ZCA and SMZCA-20, respectively. The Sauter mean diameter $(\mathrm{D}[3,2])$ was $24.3 \mu \mathrm{m}$ for $\mathrm{CCA}, 23.9 \mu \mathrm{m}$ for ZCA and $20.7 \mu \mathrm{m}$ for SMZCA-20. The D[3,2] values are indicative of the active surface area of the materials, therefore based on these results it would seem appropriate to consider SMZCA-20 as having better adsorption potential than others materials. The particle size of the modified zeolite is as a function of the amount and the mo lecular size of surfactant added.

Table 2. Physicochemical properties of zeolite from cyclone ash and modified-zeolite

\begin{tabular}{|c|c|c|}
\hline & ZCA & SMZCA-20 \\
\hline $\mathrm{SiO}_{2}$ (wt. \%) & 39.5 & 26 \\
\hline $\mathrm{Al}_{2} \mathrm{O}_{3}$ (wt. \%) & 25 & 11.6 \\
\hline $\mathrm{Fe}_{2} \mathrm{O}_{3}$ (wt. \%) & 16.6 & 45 \\
\hline $\mathrm{CaO}$ (wt. \%) & 2.68 & 5 \\
\hline Br (wt. \%) & n.a & 4.2 \\
\hline $\mathrm{TiO}_{2}$ (wt. \%) & 1.17 & 2.9 \\
\hline $\mathrm{SO}_{3}$ (wt. \%) & 1.05 & 1 \\
\hline $\mathrm{Na}_{2} \mathrm{O}$ (wt. \%) & 11.8 & 0.78 \\
\hline Others (wt. \%) & 1.8 & 1.76 \\
\hline $\mathrm{pH}$ in water & 9.23 & 8.87 \\
\hline $\mathrm{pH}$ & 9.04 & 8.44 \\
\hline Specific surface area $\left(\mathrm{m}^{2} \mathrm{~g}^{-1}\right)$ & 39 & 14.6 \\
\hline CEC (meq $\left.100 \mathrm{~g}^{-1}\right)$ & 137.6 & - \\
\hline $\operatorname{ECEC}\left(\right.$ meq $\left.100 \mathrm{~g}^{-1}\right)$ & 39.7 & - \\
\hline
\end{tabular}

$\mathrm{n} . \mathrm{a}=$ data not available; $\mathrm{pH}_{\mathrm{PZC}}=$ point of zero charge; $\mathrm{CEC}=$ cation exchange capacity; ECEC = external cation exchange capacity
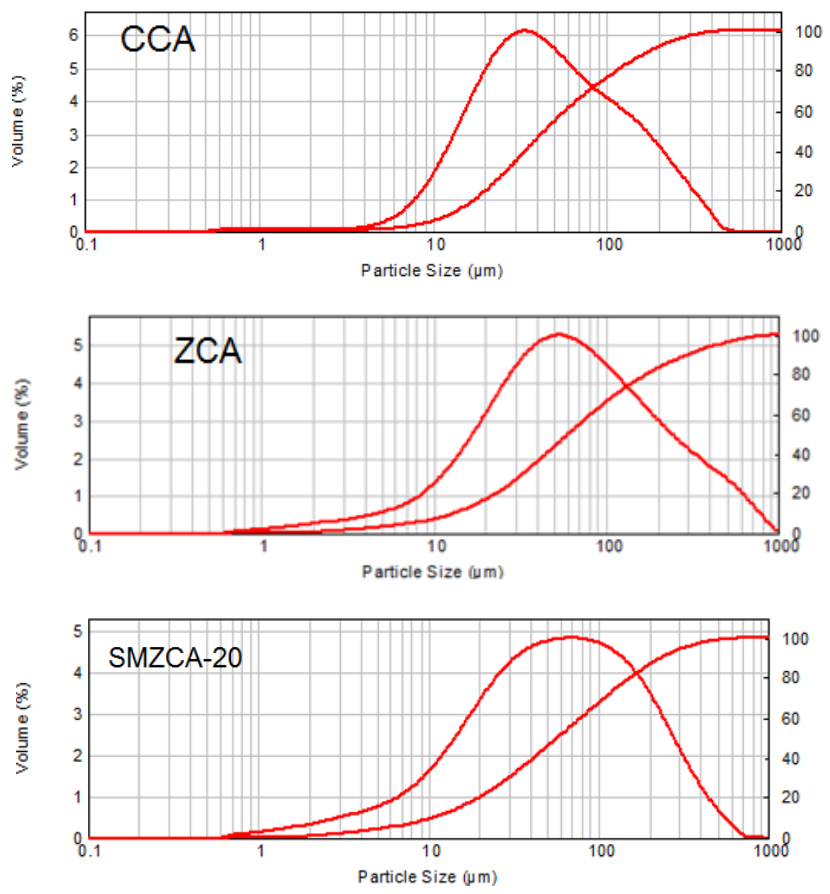

Figure 3. Particle size distribution of CCA, ZCA and SMZCA-20

Table 3. Particle size distributions of materials

\begin{tabular}{|c|c|c|c|}
\hline Sample & $\mathrm{D}_{10}(\mu \mathrm{m})$ & $\mathrm{D}_{50}(\mu \mathrm{m})$ & $\mathrm{D}_{90}(\mu \mathrm{m})$ \\
\hline CCA & 13.579 & 43.624 & 174.833 \\
\hline ZCA & 12.965 & 59.928 & 291.832 \\
\hline SMZCA-20 & 10.449 & 57.092 & 230.022 \\
\hline
\end{tabular}

Fly ash has a broad size distribution with diameters spanning more than three orders of magnitude. The median diameters of ashsamples from six representative coals collected in cyclones and baghouses of american coal fired power plants were between $1.2-3.4 \mu \mathrm{m}$ and $0.4-$ $1.2 \mu \mathrm{m}$, respectively [28].

The grain size distribution of fly ash sample from a Brazilian power plant (Presidente Medici Power Plant or UTPM-446 MW) collected from electrostatic precipitator was determined. The continuous interval of particle sizes was between 0.5 and $600 \mu \mathrm{m}$, and the average diameter was $49.30 \mu \mathrm{m}$. Ninety percent of the particles have diameters smaller than $232 \mu \mathrm{m}$, while the finest particles 
(<5 $\mu \mathrm{m}$ ) correspond to $\sim 1 \%$ of the total mass of the sample [29].

Table 4 presents the trace elemental concentration in CCA, ZCA and SMZCA-20 samples obtained by instrumental neutron activation analyses. A considerable reduction in the elements contents was attained in the fly ash zeolitization for arsenic and zinc that decreased between $86-90 \%$ and $16-25 \%$, respectively. A significant amount of $\mathrm{Na}$ element is incorporated in the zeolitic products after hydrothermal treatment with $\mathrm{NaOH}$ solution due to entrapment of sodium ions to neutralize the negative charge on aluminosilicate gel [30]. The presence of bromide in the modified zeolitic material was detected. The positive charge of cation HDTMA adsorbed on the surface of the zeolite is counterbalanced by anions bromide. The other elements are present in approximately the same amount in the three samples.

Table 4. Chemical elements in CCA, ZCA and SMZCA-20 samples analyzed by INAA

\begin{tabular}{|c|c|c|c|}
\hline \multirow{2}{*}{ Element } & \multicolumn{3}{|c|}{ Concentration $\left(\mu \mathrm{g} \mathrm{g}^{-1}\right)^{1}$} \\
\cline { 2 - 4 } & $\mathrm{CCA}$ & ZCA & SMZCA-20 \\
\hline $\mathrm{As}$ & $632 \pm 95$ & $64 \pm 7$ & $86 \pm 3$ \\
\hline $\mathrm{Br}$ & $<\mathrm{dl}$ & $4.0 \pm 1.2$ & $5060 \pm 1320$ \\
\hline $\mathrm{Co}$ & $24.0 \pm 0.1$ & $26.4 \pm 0.8$ & $24.7 \pm 0.5$ \\
\hline $\mathrm{Cr}$ & $93 \pm 6$ & $103 \pm 6$ & $79 \pm 23$ \\
\hline $\mathrm{Eu}$ & $4.1 \pm 0.1$ & $4.6 \pm 0.1$ & $4.3 \pm 0.1$ \\
\hline $\mathrm{Fe}$ & $95100 \pm 4076$ & $100973 \pm 4538$ & $88549 \pm 13299$ \\
\hline $\mathrm{La}{ }^{*}$ & $121 \pm 4$ & $147 \pm 147$ & $145 \pm 4$ \\
\hline $\mathrm{Na}$ & $8293 \pm 50$ & $76884 \pm 530$ & $63435 \pm 270$ \\
\hline $\mathrm{Sb}$ & $8.3 \pm 0.4$ & $2.5 \pm 0.5$ & $2.2 \pm 0.6$ \\
\hline $\mathrm{Sc}$ & $25.8 \pm 0.6$ & $27.5 \pm 0.7$ & $25 \pm 3$ \\
\hline $\mathrm{Sm}$ & $19 \pm 1$ & $19.3 \pm 0.3$ & $24 \pm 1$ \\
\hline $\mathrm{Th}$ & $23.9 \pm 1.1$ & $26.5 \pm 0.7$ & $20 \pm 3$ \\
\hline $\mathrm{U}$ & $227 \pm 11$ & $256 \pm 29$ & $266 \pm 9$ \\
\hline $\mathrm{Zn}$ & $822 \pm 82$ & $689 \pm 1$ & $620 \pm 1$ \\
\hline
\end{tabular}

(1) Mean and standard deviation of two determinations; $(*)$ element that can be fission products; $\mathrm{dl}=$ detection limit

The high concentrations of $\mathrm{As}, \mathrm{Fe}$ and $\mathrm{Zn}$ are due to the high content of pyrite of the feed coal. Concentrations of $\mathrm{U}$ are relatively high because the area near Figueira coalfired power plant is rich in uranium, with an average of $0.148 \% \mathrm{U}_{3} \mathrm{O}_{8}$ in calcitic sandstone above the coal seam $[1,31]$.

\section{3. dsorption Knetics}

To determine the equilibration concentration and time, the adsorption of the RO16 onto zeolites was studied as a function of contact time. These experiments were performed against time (range 10-80min for ZCA and 1$60 \mathrm{~min}$ for SMZCA-20) and the effect of equilibrium time on the adsorption of RO16 onto the unmodified and modified zeolites is presented in Figure 4.

It should be pointed out that apparent equilibrium was reached after $120 \mathrm{~min}$ for ZCA. The adsorption of RO16 onto modified zeolite was almost instantaneous and an apparent equilibrium was reached within the first $5 \mathrm{~min}$. The adsorption capacities of unmodified zeolite are low and when zeolite was modified with HDTMA-Br, the adsorption capacities were increased remarkably. The degree of removal of RO16 was $100 \%$ for concentrations $<25.0 \mathrm{mg} \mathrm{L}^{-1}$ using SMZCA-20.
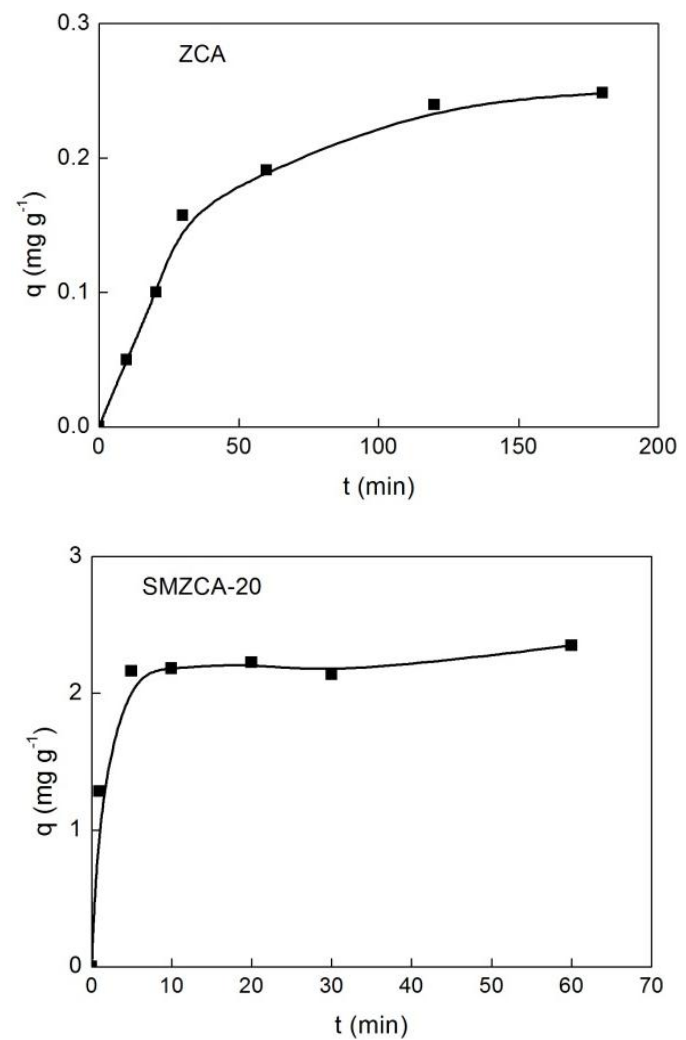

Figure 4. Influence of equilibrium time on the adsorption of RO16 on ZCA and SMZCA-20

It is important to be able to predict the rate at which contamination is removed from aqueous solutions in order to design an adsorption treatment plant. Aiming at evaluating the adsorption kinetics of RO16 onto zeolites, the pseudo-first order, pseudo-second order and intraparticle diffusion kinetic models were used to fit the experimental data, according to the kinetic model equations (3) to (6). The values of kinetic constants for RO16 adsorption onto unmodified zeolite and surfactantmodified zeolite are presented in Table 5.

Table 5. Kinetic parameters for the removal of RO16 by zeolite from cyclone ash and surfactant-modified zeolite

\begin{tabular}{|c|c|c|}
\hline & ZCA & SMZCA-20 \\
\hline Pseudo- first order & & \\
\hline $\mathrm{K}_{1}\left(\mathrm{~min}^{-1}\right)$ & $2.66 \times 10^{-2}$ & $2.36 \times 10^{-2}$ \\
\hline $\mathrm{q}_{\mathrm{e}} \mathrm{calc}\left(\mathrm{mg} \mathrm{g}^{-1}\right)$ & 0.232 & 0.0339 \\
\hline $\mathrm{q}_{\mathrm{e}} \mathrm{exp}\left(\mathrm{mg} \mathrm{g}^{-1}\right)$ & 0.229 & 2.35 \\
\hline $\mathrm{R}_{1}$ & 0.989 & 0.579 \\
\hline & & \\
\hline Pseudo- second order & & $39.4 \times 10^{-2}$ \\
\hline $\mathrm{K}_{2}\left(\mathrm{~g} \mathrm{mg}^{-1} \mathrm{~min}^{-1}\right)$ & $13.2 \times 10^{-2}$ & 2.18 \\
\hline $\mathrm{h}\left(\mathrm{mg} \mathrm{g}^{-1} \mathrm{~min}^{-1}\right)$ & 0.0109 & 2.36 \\
\hline $\mathrm{q}_{\mathrm{e}} \mathrm{calc}\left(\mathrm{mg} \mathrm{g}^{-1}\right)$ & 0.286 & 2.35 \\
\hline $\mathrm{q}_{\mathrm{e}} \mathrm{exp}\left(\mathrm{mg} \mathrm{g}^{-1}\right)$ & 0.229 & 0.999 \\
\hline $\mathrm{R}_{2}$ & 0.999 & \\
\hline & & 0.955 \\
\hline Intraparticle diffusion & & $4.73 \times 10^{-2}$ \\
\hline $\mathrm{C}\left(\mathrm{mg} \mathrm{g}^{-1}\right)$ & 0.0965 & 0.747 \\
\hline $\mathrm{K}_{\mathrm{i}}\left(\mathrm{mg} \mathrm{g}^{-1} \mathrm{~min}^{-0.5}\right)$ & $1.198 \times 10^{-2}$ & \\
\hline $\mathrm{R}_{\mathrm{i}}$ & 0.978 & $\mathrm{correlation}$ \\
\hline
\end{tabular}

It is obvious from Table 5 that the correlation coefficients $\mathrm{R}_{2}$ for the linear plots of the pseudo-second 
order model is 0.999 which is higher than the correlation coefficients $R_{1}$ for the pseudo-first order and the calculated $\mathrm{q}_{\mathrm{e}}$ values are in agreement with experimental $\mathrm{q}_{\mathrm{e}}$ values. This indicates that the adsorption kinetic is better represented by the pseudo-second order model.

The intraparticle rate constants were obtained from the plot of $\mathrm{q}$ versus $\mathrm{t}^{05}$ and the results are given in Table 5 . The $\mathrm{C}$ values indicate that the line did not pass through the origin. It has been reported by various researchers that when the plots do not pass through the origin, this is indicative of some degree of boundary layer control and further shows that the intraparticle diffusion is not only the rate controlling step, but some other processes may also control the rate of adsorption.

\subsection{Adsorption Isotherm}

Langmuir and Freundlich models were applied to describe equilibrium adsorption is otherms for RO16 onto the ZCA and SMZCA-20 samples at $25^{\circ} \mathrm{C}$, and the fits of the theoretical models to the experimental values are shown in Figure. 5. The is otherm constants, their correlation coefficients and value of Chi-square test calculated from Eq. (7)-(9) are given in Table 6. For analysis of data using linear regression, the fitness of the model is often evaluated based on the value of the correlation coefficients $\left(R^{2}\right)$. Both Langmuir and Freundlich isotherms give similar $R^{2}$ values for ZCA and SMZCA-20. Despite this, the $\chi^{2}$ values for Freundlich were very large, mainly for ZCA, suggesting that the is otherm constants of Freundlich obtained from the linear regression do not describe well the equilibrium data.
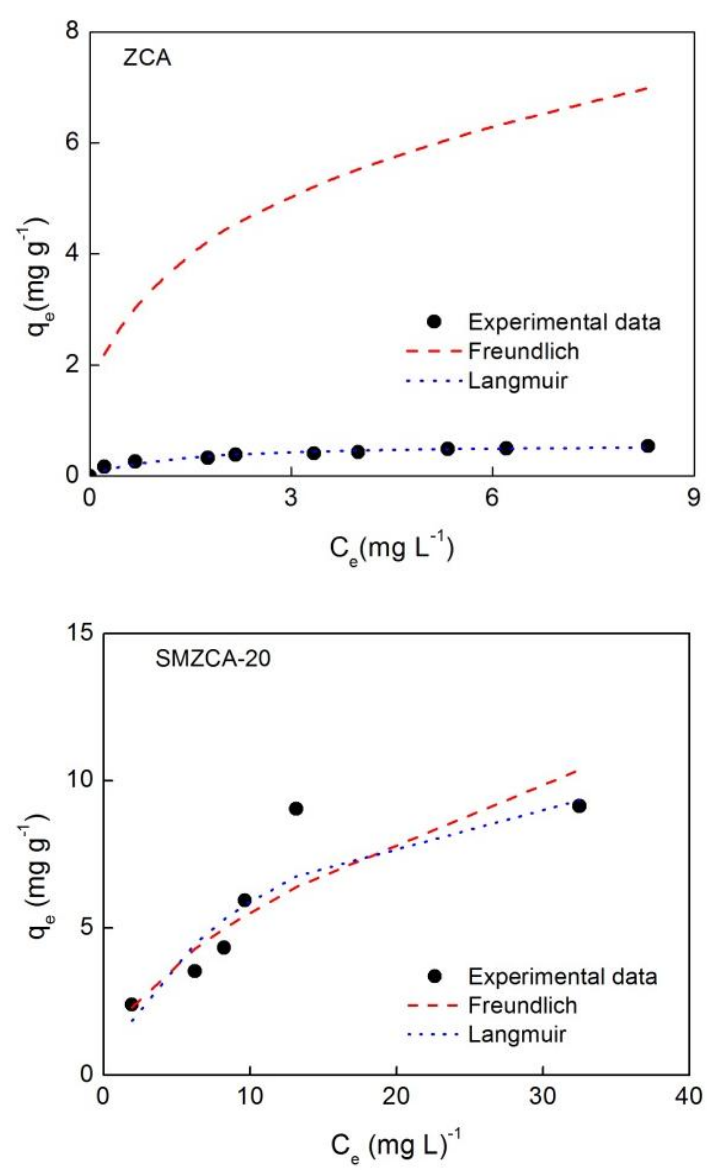

Figure 5. Equilibrium isotherms for the removal of RO16 by ZCA and SMZCA-20
The RO16 maximun adsorption capacity $\left(\mathrm{Q}_{0}\right)$ of the ZCA sample is $0.580 \mathrm{mg} \mathrm{g}^{-1}$. After surface modification with HDTMA, dye ion removal is greatly enhanced to $12.6 \mathrm{mg} \mathrm{g}^{-1}$. Adsorption by zeolite is negligible presumably because of the strong dipole interaction between zeolite and water, which excludes organic solutes from this portion of the zeolite.

The measurements of $\mathrm{pH}_{\mathrm{PZC}}$ revealed that surfactantmodified zeolite sample surface acquires a negative charge in water at natural $\mathrm{pH}$ (Table 2). The negative charge of SMZCA-20 is probably due to the formation of a patchy bilayer on the number of exchangeable active sites on the external zeolite surface [11].

Table 6. Comparis on of equilibrium isotherm models

\begin{tabular}{|c|c|c|}
\hline Isotherm & \multicolumn{2}{|c|}{ Adsorbents } \\
\hline Langmuir & ZCA & SMZCA-20 \\
\hline $\mathrm{Q}_{0}\left(\mathrm{mg} \mathrm{g}^{1}\right)$ & 0.58 & 12.6 \\
\hline $\mathrm{b}\left(\mathrm{L} \mathrm{mg}^{-1}\right)$ & 0.966 & 0.0878 \\
\hline $\mathrm{R}^{2}$ & 0.993 & 0.93 \\
\hline$\chi^{2}$ & 0.0533 & 1.32 \\
\hline Freundlich $\left.^{-1}\left(\mathrm{~L} \mathrm{mg}^{-1}\right)^{1 / h}\right]$ & 3.56 & 1.61 \\
\hline $\mathrm{n}$ & 3.14 & 1.87 \\
\hline $\mathrm{K}_{\mathrm{f}}\left[\left(\mathrm{mg} \mathrm{g}^{2}\right.\right.$ & 0.994 & 0.926 \\
\hline$\chi^{2}$ & 37.6 & 1.52 \\
\hline
\end{tabular}

The adsorption of RO16 onto SMZCA-20 with patchy bilayer coverage is attributed to multiple mechanis ms, such as, electrostatic interaction, hydrogen bonding, hydrophobic interaction and ion exchange. Hydrophobic interaction and hydrogen bonding are suggested to be the predominant mechanisms. Hydrophobic interaction involves the hydrophobic tails of HDTMA and the hydrophobic functional groups of RO16 molecules, and this mechanism is of London-Van der Waals type [32].

A large number of hydrogen bonds between $\mathrm{C}$ or $\mathrm{N}$ of HDTMA and alkyl, aromatic and sulphonic groups of RO16 also is responsible for the effective adsorption. The aromatic and sulfonate groups of organic compounds and their planar shape and delocalized $\pi$-bonds interact strongly with ammoniu m centers of HDTMA [33,34,35].

A comparison of the adsorption maxima of RO16 on zeolite from cyclone fly ash (ZCA) and surfactant modified zeolite from cyclone ash (SMZCA-20) with those of some low cost adsorbents reported in the literature is given in Table 7. As seen in Table 7, the SMZCA-20 had comparable adsorption performances with chitosan cross-linked beads.Although activated carbon from waste materials $[36,37,38]$ and various types of sludge [39] presents high efficiency in the removal of RO16, the obtaining of these adsorbents requires optimization of the preparation process involving several steps anduse of relatively expensive chemical reagents [40].

Adsorption capacity for unmodified zeolites increased with decreasing adsorbent particle size. Zeolites from baghouse ash have smaller particle size than zeolitesfrom cyclone ash. The increase in adsorption capacity with decreasing adsorbent particle size is attributable to molecules adsorbing principally in the exterior region close to the external particle surface [44]. The specific external surface area (surface area per unit mass) available for adsorption would be greater for smaller adsorbent 
particles. The values of BET surface area were 69.3 and $39.0 \mathrm{~m}^{2} \mathrm{~g}^{-1}$ for zeolite from baghouse fly ash and zeolite from cyclone ash, respectively.

Table 7. Comparison of the maximum monolayer adsorption capacities of RO16 on various adsorbents

\begin{tabular}{|c|c|c|}
\hline Adsorbent & $\begin{array}{c}\text { Maximum } \\
\text { Adsorption Capacity } \\
\left(\mathrm{mg} \mathrm{g}^{-1}\right)\end{array}$ & Reference \\
\hline Corn cob & $22.0-26.1$ & 41 \\
\hline Chitosan cross-linked (beads) & $5.6-30$ & 42 \\
\hline Quartenized Sugar Cane Bagasse & 34.48 & 43 \\
\hline $\begin{array}{c}\text { Zeolite from baghouse fly ash-iron } \\
\text { oxide }\end{array}$ & 1.06 & 44 \\
\hline Zeolite from baghouse fly ash & 1.14 & 19 \\
\hline Zeolite from cyclone fly ash & 0.58 & This study \\
\hline $\begin{array}{c}\text { Surfactant modified zeolite from } \\
\text { cyclone ash }\end{array}$ & 12.6 & This study \\
\hline
\end{tabular}

\subsection{Effect of Adsorbent Dosage}

The influence of SMZCA-20 dosage on RO16 removal was studied and the results are presented in Figure. 6. As the adsorbent dosage increased, a greater surface area and a greater number of binding sites should be available for the constant amount of RO16, which results in the percentage removal of RO16 increasing with increasing SMZCA-20 dose. The highest amount of dye removal was attained for adsorbent dose of $10 \mathrm{~g} \mathrm{~L}^{-1}$. For adsorbent dosages higher than this value, the percentage of the dye removal and the amount of dye uptake per gram of adsorbent $\left(\mathrm{q}_{\mathrm{e}}\right)$ remained almost constant.

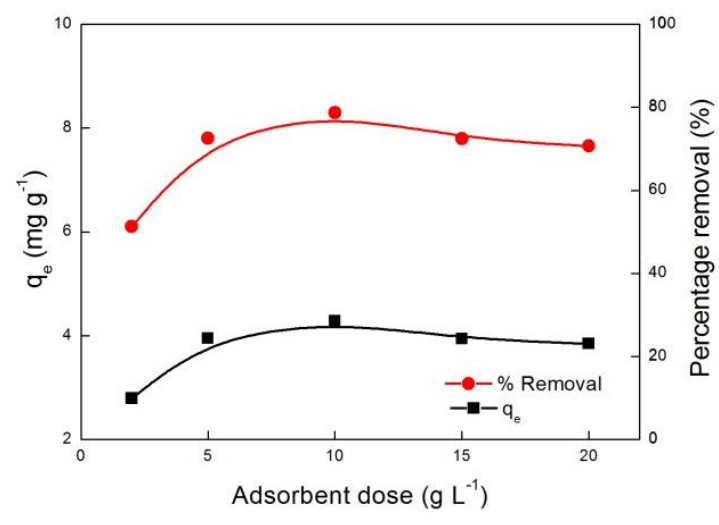

Figure 6. Effect of adsorbent dose on the adsorption of RO16 onto SMZCA-20 (contact time: $60 \mathrm{~min}$; initial dye concentration: $50 \mathrm{mg} \mathrm{L}^{-1}$ )

\subsection{Effect of Initial pH}

The effect of $\mathrm{pH}$ on the RO16 anions uptake by SMZCA-20 is shown in Figure 7. The amount adsorbed remained constant in the $\mathrm{pH}$ interval between 2 to 9 and increased with the medium $\mathrm{pH} 10$. The hydrophobic interactions between RO16 and HDTMA chains appears to be the most important mechanis $\mathrm{m}$ involved in anionic dye adsorption in the case where the $\mathrm{pH}$ does not play any role on adsorption process. The increase in RO16 removal in $\mathrm{pH} 10$ may be due to strong basic nature of the loaded HDTMA on ZCA.

\subsection{Acute Toxicity Test}

The dye to xicity was evaluated for dye solutions before and after the adsorption processes with $D$. simlis and $V$. ficheri.In the present study, toxicity was evaluated at
RO16 concentrations of $6.25-100 \mathrm{mg} \mathrm{L}^{-1}$ and 10.23 $81.90 \mathrm{mg} \mathrm{L}^{-1}$ for to determine $\mathrm{EC}_{50}$ ranges forD. simlis and $V$. ficheri, respectively.

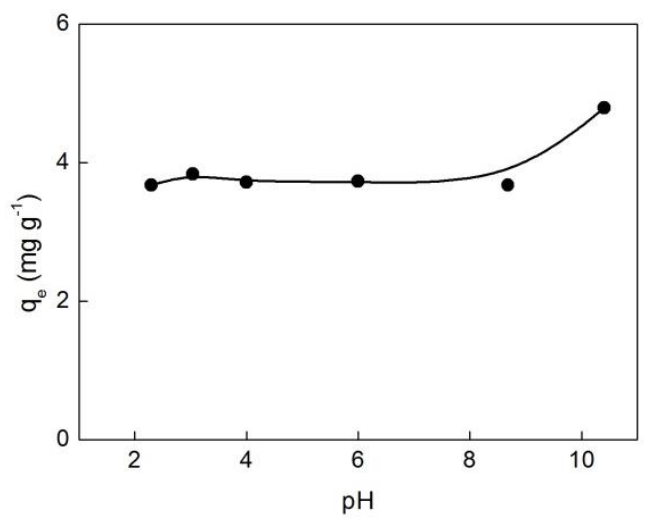

Figure 7. Effect of pH on the adsorption of RO16 onto SMZCA-20 (contact time: $60 \mathrm{~min}$; initial dye concentration: $50 \mathrm{mg} \mathrm{L}^{-1}$ )

The results indicate that the $\mathrm{EC}_{50}$ of $\mathrm{RO} 16$ were 16.72 and $92.10 \mathrm{mg}^{-1}$ for $V$. ficheri and D. simlis, respectively.This means that the concentration values of the dye used are considered toxic to the aquatic environment and that color removal is required. After treatment of RO16 by SMZCA-20, $\mathrm{EC}_{50}$ value was $0.32 \mathrm{mg} \mathrm{L}^{-1}$ for D. simlis and 1.32 for $\mathrm{mg} \mathrm{L}^{-1} V$. ficheri. One possible reason for this increase in toxicity after treatment could be due to the presence of residual surfactant in the effluent. This hypothes is was confirmed by toxicity tests carried out with dyes solutions after adsorption process using unmodified zeolite from fly ash. It was observed that acute effects were substantially reduced or was eliminated after the adsorption treatment $[6,46,47]$.

\section{Conclusion}

This study investigated the equilibrium and the dynamics the adsorption of an anionic dye, which is namely Reactive Orange 16 dye, RO16, onto unmodified zeolite (ZCA) and surfactant-modified zeolite (SMZCA) that were synthesized from cyclone ash. The best conditions were established with respect to contact time, adsorbent dose and $\mathrm{pH}$ to saturate the available sites located on the SMZCA surface. The pseudo-second order kinetic model agrees very well with the dynamic behavior for the adsorption of RO16 onto adsorbents. The experimental data fitted well to the Langmuir adsorption isotherm. The ecotoxicity studies showed the wastewater contaminated with dyes after treatment with modifiedsurfactant zeolite should not be discarded directly into water bodies, but can be used as non-potable water reuse. Although zeolite synthesized from cyclone ash showed little adsorption for RO16, surface modified zeolite material proved to be an effective adsorbent for the adsorption of anionic azodye compound from wastewater.

\section{Acknowledgement}

The authors are grateful to Conselho Nacional de Desenvolvimento Científico e Tecnológico (CNPq) for 
financial support and to Carbonífera do Cambuí (Figueira Power Plant) for providing cyclone fly ash samples for this study.

\section{References}

[1] Depoi, F.S., Pozebon, D. and Kalkreuth, W.D. "Chemical characterization of feed coals and combustion-by-products from Brazilian power plants," International Joumal of Coal Geology, 76, 227-236, 2008

[2] Shanthakumar, S., Singh, D.N. and Phadke, R.C. "Flue gas conditioning for reducing suspended particulate matter from thermal power stations" Progress in Energy and Combustion Science, 34, 685-695, 2008.

[3] Silva, L.F.O. and da Boit, K.M. "Nanominerals and nanoparticles in feed coal and bottom ash: implications for human health effects," Environmental Monitoring and Assessment, 174, 187-197, 2011.

[4] Font, O., Córdoba, P., Leiva, C., Romeo, L.M., Bolea, I., Guedea, I., Moreno, N., Querol, X., Fernandez, C. and Díez, L.I., "Fate and abatement of mercury and other trace elements in a coal fluidised bed oxy combustion pilot plant," Fuel, 95, 272-281, 2012.

[5] Fungaro, D.A., Bruno, M. and Grosche, L.C. "Adsorption and kinetic studiesof methylene blue on zeolite synthesized from fly ash," Desalination and Water Treatmen, 2, 231-239, 2009.

[6] Fungaro, D.A., Grosche, L.C., Pinheiro, A.S., Izidoro, J.C. and Borrely, S.I. "Adsorption of methylene blue from aqueous solution on zeolitic material and the improvement as toxicity removal to living organisms, "Orbital, 2, 235-247, 2010.

[7] Fungaro, D.A., Yamaura, M. and Carvalho, T.E.M. “Adsorption of anionic dyes from aqueous solution on zeolite from fly ash-iron oxide magnet ic nanocomposite," Journal of Atomic and Molecular Sciences, 2, 305-316, 2011

[8] Bowman, B.S. "Applications of surfactant-modified zeolites to environmental remediation.Review," Microporous Mesoporous Materials, 6, 43-56, 2003.

[9] Haggerty, G.M. and Bowman, R.S. "Sorption of chromate and other inorganic anions by organo-zeolite," Environmental Science \& Technology, 28, 452-458, 1994.

[10] Li, Z. and Bowman, R.S. "Counterion effects on the sorption of cationic surfactant and chromate on natural clinoptilolite," Environmental Science \& Technology, 31, 2407-2412, 1997.

[11] Fungaro, D.A. and Borrely, S.I. "Synthesis and characterization of zeolite from coal ashes modified by cationic surfact ant," Cerâmica, 58, 77-83, 2012. (in Portuguese with English abstract)

[12] Guan, H., Bestland, E., Zhu, C., Zhu, H., Albertsdottir, D., Hut son, J., Simmons, C.T., Ginic-Markovic, M., T ao, X. and Ellis, A.V. "Variation in performance of surfactant loading and resulting nitrate removal among four selected natural zeolites," Journal of Hazardous Materials, 183, 61 6-621, 2010.

[13] Li, Z.H. "Sorption kinetics of hexadecyltrimethylammonium on natural clinoptilolite," Langmuir, 15, 6438-6445, 1999.

[14] Li, Z.H. and Bowman, R.S. "Sorption of perchloroethylene by surfact ant-modified zeolite as controlled by surfactant loading," Environmental Science \& Technology, 32, 2278-2282, 1998.

[15] Rozic, M., Sipusic, D.I., Sekovanic, L., Miljanic, S., Curkovic, L. and Hrenovic, J. "Sorption phenomena of modification of clinoptilolite tuffs by surfactant cations," Joumal of Colloid and Interface Science, 331, 295-301, 2009.

[16] Mumford, J.L. and Lewtas, J. "Evaluation of fly ash collection methods for short-term bioassay studies of fluidized-bed coal combustion," Environmental Science \& Technology, 18, 765-768, 1984.

[17] Easton, JR. The dyemaker's view. Society of Dyers and Colourists; The Alden Press, Oxford, 9-21, 1995.

[18] Novotny, C., Dias, N., Kapanen, A., Malachova, K., Vandrovcova, M., Itavaara, M. and Lima, N. " Comparat ive use of bacterial, algal and protozoan tests to study toxicity of azo- and anthraquinone dyes," Chemosphere, 63, 1436-1442, 2006.

[19] Carvalho, T.E.M., Fungaro, D.A., Magdalena, C.P. and Cunico. P. "Adsorption of indigo carmine from aqueous solution using coal fly ash and zeolite from fly ash," Joumal of Radioanalytical and Nuclear Chem istry,289, 617-626, 2011.

[20] Henmi, T., "Increase in cation exchange capacity of coal fly ash by alkali treatment," Clay Science, 6, 277-282, 1987.
[21] Blanchard, G., Maunaye, M.and Martim, G. "Removal of heavy metals from waters by means of nat ural zeolites," Water Research 18, 1501-1507,1984.

[22] Ho, Y.S. and McKay, G. "Sorption of dye from aqueous solution by peat," Chemical Engineering Joumal, 70, 115-12, 1998.

[23] Ho, Y.S. and McKay, G. "Pseudo-second order model for sorption processes," Process Biochem istry, 34, 451-465, 1999.

[24] Weber, W.J. and Morris, J.C. "Kinetics of adsorption carbon from solutions," Joumal Sanitary Engeering Division Proceeding s.American Society of Civil Engineers, 89, 31-60, 1963.

[25] Ho, Y.S. "Selection of optimum sorption isotherm," Carbon, 42, 2115-2116, 2004

[26] CETESB - Companhia Ambiental do Estado de São Paulo. "Água: Testes de toxicidade aguda com Daphnia similis" Claus, 1976(Cladocera, Crustácea). L5.019-1, São Paulo, 28 pp, 1986.

[27] CETESB - Companhia Ambiental do Estado de São Paulo. "Bioensaio de toxicidade aguda com Photobacterium phosphoreum. Sistema Microtox” São Paulo, 1987.

[28] Ghosal, S., Ebert, J.L. and Self.S.A. "Chemical composition, size distributions for fly ashes",Fuel Processing Technology, 44, 81-94, 1995.

[29] Pires, M. and Querol, X. "Characterization of Candiota (South Brazil) coal and combustion by-product," Intemational Joumal of Coal Geology, 60, 57-72, 2004.

[30] Murayama, N., Yamamoto, H., and Shibata, J. "Mechanism of zeolite synthesis from fly ash by alkali hydrothermal reaction," Intemational Journal of Mineral Processing, 64, 1-17, 2002.

[31] Flues, M., Camargo, I.M.C., Figueiredo Filho, P.M., Silva, P.S.C. and Mazzilli, B.P. "Evaluation of radionucletides concentration in Brazilian Coals" Fuel, 86, 807-812, 2007.

[32] Dong, Y, Wu, D.Y., Chen, XC and Lin, Y. "Adsorption of bisphenol A from water by surfactant-modified zeolite," Journal of Colloid and Interface Science, 348, 585- 59, 2010.

[33] Sheng, G., Xu, S., Boyd, S.A. "Mechanism(s) controlling sorption of neutral organic contaminants by surfact ant-derived and nat ural organic matter," Environmental Science \& Technology, 30:15531557,1996

[34] Custelcean, R. and Jackson, J.E. "Dihydrogen bonding: structures, energetics, and dynamics," Chemical Reviews, 101, 1963-1980, 2001.

[35] Stefov, V., Pejov, L. and Soptrajanov, B. "Experimental and quantum chemical study of pyrrole self-association through $\mathrm{N}-$ H... $[\pi]$ hydrogen bonding." Joumal of MolecularStructure, 649, 231-243, 2003

[36] Lee, J.W., Choi, S.P., Thiruvenkatachari, R., Shim, W.G. and Moon, H. "Submerged microfiltration membrane coupled with alum coagulation/powdered activated carbon adsorption for complete decolorization of reactive dyes," Water Reseaerch, 40, 435-444, 2006.

[37] Calvete, T., Lima, E.C., Cardoso, N.F., Vaghetti, J.C., Dias S.L., and Pavan, F.A. "Application of carbon adsorbents prepared from Brazilian-pine fruit shell for the removal of reactive orange 16 from aqueous solution: Kinetic, equilibrium, and thermodynamic studies," Journal of Environmental Management, 91, 1695-706, 2010.

[38] Ramachandran, P., Vairamuthu, R., Ponnusamy, S. "Adsorption isotherms, kinetics, thermodynamics and desorption studies of reactive orange16 on activated carbon derived from Ananas comosus (L.) Carbon," Journal of Engineering \& Applied Sciences; 6, 15-26, 2011.

[39] Won, S.W., Choi, S.B. and Yun, Y.S. "Performance and mechanism in binding of Reactive Orange 16 to various types of sludge," Biochemical Engineering Joumal, 28, 208-214, 2006.

[40] Dias, J.M., Alvim-Ferraz, M.C.M., Almeida, M.F., Rivera-Utrilla, J. and Sanchez-Polo, M. "Waste materials for activated carbon preparation and its use in aqueous-phase treatment: a review," Journal of Environmental Managem ent, 85, 833-846, 2007.

[41] Suteu, D., Malutan, T. and Bilba, D. "Agricultural waste corn cob as a sorbent for removing reactive dye orange 16: equilibrium and kinetic study," Cellulose Chemistry and Technology, 45,413-420, 2011.

[42] Kimura, I.Y., Laranjeira, M.C.M., Fávere, V.T. and Furlan, L. "The interaction between reactive dye containing vinylsulfone group and chitosan microspheres," Intemational Journal of Polymeric Materials, 51, 759-768, 2002.

[43] Wong, S.Y., Tan, Y.P., Abdullah A.H. and Ong, S.T. "The Removal of Basic and Reactive Dyes using Quartenized Sugar Cane Bagasse," Journal of Physical Science 20, 59-74, 2009. 
[44] Fungaro, D. A.; Yamaura, M.; Carvalho, T. E. M.; "Adsorption of anionic dyes from aqueous solution on zeolite from fly ash-iron oxide magnetic nanocomposite," Journal of Atomic and Molecular Sciences, 2, 305-316.2011.

[45] Ando, N., Matsui, Y., Kurotobi, Y., Nakano, Y., Mat sushita, T. and Ohno, K. "Comparison of nat ural organic matter adsorption capacities of super-powdered activated carbon and powdered activated carbon," Water Research, 44, 4127-4136, 2010.
[46] Magdalena, C.P. "Adsorption of reactive remazol red RB dye of aqueous solution using zeolite of the coal ash and evaluation of acute toxicity with Daphnia similis,"

http://pelicano.ipen.br/PosG30/TextoCompleto/Carina\%20Pit wak \%20Magdalena_M.pdf, 2010 (in Portuguese with English abstract).

[47] Ferreira, C.P. "Studies on the adsorption of reactive black 5 dye of aqueous solution using zeolite of the coal ashes,"

http://pelicano.ipen.br/PosG30/TextoCompleto/Patricia\%20Cunic o\%20Ferreira_M.pdf, 2011 (in Portuguese with English abstract). 